\title{
Proceeding
}

Supplementary Issue: Summer Conferences of Sports Science. First International Conference in Iraq on Sport for Peace, 4 April 2019. Baghdad Science Institute, Baghdad, Iraq.

\section{Comparative research of job satisfaction among the doctor personnel in the Russian federation, under conditions of "performance-based contract of employment"}

\author{
SERGEY KUCHITS ${ }^{1}$, OLEG GRIDNEV², ELENA PESENNIKOVA $\triangle$, GELIA GILDEEVA², DILBAR \\ ANDREEVA2 \\ ${ }^{1}$ Regional Vascular Center of the Moscow State City University Clinic named after M.P. Konchalovsky of \\ Moscow Health Department, Moscow, Russia \\ 2Institute of Postgraduate Education, First Moscow State Medical University named after I.M. Sechenov, \\ Moscow, Russia \\ ${ }^{3}$ Department of Management in the Sphere of Medicine Circulation at Institute of Postgraduate Education, \\ First Moscow State Medical University named after I.M. Sechenov, Russia
}

\begin{abstract}
Employee satisfaction with work is one of the most important factors in the effectiveness of a health care organization, which contributes to the development of the personnel potential of an institution and has a direct impact on the quality of health care services provided. The purpose of this study is to compare the levels of satisfaction with the work of doctors in Russian and foreign organizations that used a "performance-based contract of employment" with employees. They were requested to consider their overall attitude to their job and the level of satisfaction with such parameters as wages, working conditions and atmosphere in the team. Research findings in Russia indicated that doctors with the highest levels of work satisfaction are in the private section (67\%), while doctors in the public and departmental sections have much less levels of satisfaction (59\% and $54 \%)$. Investigating satisfaction with wages, it was found that doctors working in public institutions have a lower level of satisfaction (60\%), compared with doctors working in other types of clinics. Most of the surveyed doctors, in all types of organizations, expressed satisfaction with the team condition in the workplace (70\%). Keywords: Labour motivation; Health care; Performance-based contract of employment; Labour contract; Material incentives; Employee performance; Labour costs; Incentive payments; Job satisfaction.
\end{abstract}

Cite this article as:

Kuchits, S., Gridnev, O., Pesennikova, E., Gildeeva, G., \& Andreeva, D. (2019). Comparative research of job satisfaction among the doctor personnel in the Russian federation, under conditions of "performance-based contract of employment". Journal of Human Sport and Exercise, 14(5proc), S2116-S2126. doi:https://doi.org/10.14198/jhse.2019.14.Proc5.32

Corresponding author. Department of Management in the Sphere of Medicine Circulation at Institute of Postgraduate Education, First Moscow State Medical University named after I.M. Sechenov, Russia.

E-mail: samyshevez.kaz2@gmail.com

Supplementary Issue: Summer Conferences of Sports Science. First International Conference in Iraq on Sport for Peace, 4 April 2019. Baghdad Science Institute, Baghdad, Iraq.

JOURNAL OF HUMAN SPORT \& EXERCISE ISSN 1988-5202

(c) Faculty of Education. University of Alicante

doi:10.14198/jhse.2019.14.Proc5.32 


\section{INTRODUCTION}

The implementation of an performance-based contract of employment in a health care institution requires not only strict adherence to labour legislation, but also the determination of the labour function, indicators and criteria for evaluating performance, the amount of remuneration, the procedure and the amount of incentive for achieving comprehensive labour results for each health care worker [Kadyrov, 2013]. However, the success of any organization in the health care sphere depends on different factors. At the same time, an important factor determining the fidelity of the chosen policy of an "performance-based contract of employment" in a medical organization, directly affecting the organization's efficiency and the full disclosure of its potential by employees is Job Satisfaction (JS) among medical workers. The importance of this factor is universally recognized, but it requires additional studies of levels of satisfaction, in the face of constant changes in external conditions and social values [Shkolnikova et al, 2017]. The data obtained from the authors' own experience and a review of many foreign sources indicate that employees who are satisfied with their work are more hardworking, efficient, disciplined, and better organize their work than dissatisfied workers [Smith et al, 1969, Cooper et al, 1989] - [Lysenko et al, 2014]. So, we can expect a high level of efficiency from an organization with a high level of employee satisfaction of their work [House \& Wigdor, 1967] - [Bogue et al, 2006].

The results of surveys conducted in various countries indicate that the level of satisfaction with work among medical workers depends on many factors. [Bodrov, 2007; Medvedeva, 2008].

A survey conducted in a state Serbia clinic showed that JS is growing with the level of education of doctors [Peters et al, 2010; Jex \& Britt, 2014; Bogue et al, 2006]. At the same time, it was found that the majority of respondents $(76 \%)$ feels overworked and is not able to influence their work. Several studies evaluating job satisfaction among doctors have also been conducted in Russia. At the same time, a survey conducted in state regional hospitals in St. Petersburg and the Astrakhan region showed that more than two-thirds of doctors $(67.7 \%)$ are not satisfied with their work [Yuriev \& Tarhanov,2014]. The results also showed that a similar proportion of respondents believed that compensation for their labour was insufficient, and almost $80 \%$ of respondents said they felt overworked at work [Rose, 1994, Judge et al, 1997, Herzberg et al, 2011, Spector, 1997]

The research of labour JS is especially relevant at the present time, since "human resources" have become the main factor determining the effectiveness of an organization. There is plenty of compelling evidence that it is very difficult to manage an organization where employees have low JS. Studying a satisfaction with the work of doctors, special attention should be paid to the conditions and characteristics of their work, including the features of the functioning of organizations (state, departmental or private) where doctors work. Departmental health care institutions in Russia are created by government agencies or corporations. The purpose of such organizations is to provide medical services to a specific target group of people (employees). These organizations may also provide medical services to other patients at an additional cost [Nikic et al, 2008]. The main objective of the functioning of a state health care institution is the use of state financial resources in the most effective way, while the main goal in a private organization is to maximize profits. So, it is possible to make an assumption that a private health care institution, in comparison with a public, has a large number of incentives to develop and implement various tools to increase its effectiveness. However, public institutions tend to have the image of traditional and conservative organizations, and may adopt some practices from the private sector, especially in the area of employee motivation. Looking at the characteristics of satisfaction with the work of Russian doctors under the terms of an "performance-based contract of employment", depending on the type of institutions in which they work, and conducting a comparative analysis 
of the material received, determine the practical significance of the study, which consists in the fact that the present study is aimed at updating recommendations for managers of health care institutions on how to increase job satisfaction among medical workers in their institutions, in the context of effective about the contract. An analysis of studies related to this topic showed a small amount of work compared to job satisfaction in public and private healthcare organizations in Russia. To assess the dynamics of changes in job satisfaction among doctors in the Russian Federation, the results of this study will be compared with the results of similar studies conducted in 2010 and 2017. [Shkolnikova et al, 2017; Bussing, 2002]. The results of this study are based on a statistical analysis of primary data and cover important gaps in the scientific field, which confirms its academic significance.

\section{RESEARCH OBJECTIVE}

Comparison of the current level of JS among Russian doctors in various types of health care institutions applying a "performance-based contract of employment" to employees.

\section{MATERIALS AND METHODS}

In the process of the work, we used printed materials devoted to the problem of motivating the labour activity of medical workers, elibrary and pubmed search engines, as well as methods for the statistical processing of archival materials for monitoring economic processes in the health care sphere of the Russian Federation. The research objective was to compare the levels of JS with the work of doctors in different Moscow institutions. Data collection was carried out in 2019 in the state city, private and departmental multidisciplinary health care institutions located in Moscow. The research sample included 1876 doctors of various specializations [Silaparasetti et al, 2017]. Data collection was carried out using a specially designed questionnaire with a questionnaire covering the main components of JS with doctors and evaluating aspects of work that could affect it. For the convenience and time saving of the respondents, the questionnaire consisted of nine closed questions:

1. How long have you been working in this health care organization?

2. How satisfied are you with your work?

3. How satisfied are you with your salary?

4. How satisfied are you with your work conditions?

5. How satisfied are you with the team atmosphere in the workplace?

6. What would you like to improve in your work conditions?

7. Do you use self-studying?

8. What sources of information do you use for self-education?

9. What incentives do you consider most important to you personally?

Questionnaires were compiled subject to the anonymity of institutions and respondents. The survey was conducted only among health care workers (doctors) who expressed their consent with an anonymous study and gave their consent only on condition that their names and the names of institutions are not subject to disclosure. The research sample consisted of 916 doctors working in multidisciplinary state hospitals located in 5 distant districts of Moscow (48.8\% of the sample), 780 doctors working in 4 multidisciplinary departmental clinics $(41.6 \%$ of the sample), and 180 doctors working in 3 large private clinics in Moscow $(9.6 \%$ of the sample). That is why, the sample can be considered representative, since it reflects the proportions of doctors of different types of clinics in the corresponding general structure of health care institutions in Moscow. All response results were converted into digital data and processed using a computer program for statistical data processing "SPSS Statistics 22.0.". Data analysis included crosstabs, descriptive statistics, and logistic 
regression analysis. Logistic regression analysis was used to assess the impact of doctors' satisfaction with their salaries, working conditions and the situation in the team ("team atmosphere") in the workplace on the likelihood of respondents reporting satisfaction or dissatisfaction with their work. The basis for choosing this type of analysis was the opportunity to focus on the differences between the two groups of respondents: satisfied and dissatisfied; based on which, the dependent variable (job satisfaction) was binary. The logistic regression model was as follows: $\operatorname{Pr}=g\left(p_{0}+p_{1} X_{1}+p_{2} X_{2}+p_{3} X_{3}\right)$, where $g(z)$ is a logical function, $g(z)=1$ $I\left(1+e^{-z}\right), p_{0}$ is const., $x_{1}, x_{2}, x_{3}$ are the resulting explanatory variables "salary satisfaction", "satisfaction with work conditions", "satisfaction with the atmosphere in the team", regression coefficients $p_{1}, p_{2}, p_{3}$ and the general level of satisfaction with the work $(\mathrm{Pr})$ of doctors.

\section{RESULTS}

The average job satisfaction (JS) reported by doctors in all types of health care institutions was less than $70 \%$. The lowest indicator was found in departmental health care institutions (54.1\%) in state organizations, this indicator was slightly higher $(59.7 \%)$. The highest rate was found in private organizations $(67.1 \% ; p$ $<0.05)$. The results also demonstrated an increase in the likelihood of medical satisfaction with their work, depending on the increase in the respondent's seniority in a particular organization (Fig.1). About half of the respondents in the group with the longest work experience reported that they were satisfied with their work. At the same time, the share of satisfied doctors working in the organization for less than 1 year was $12.7 \%$. An analysis of the doctors 'satisfaction with their salaries showed that out of the total number of respondents who were completely satisfied with their salaries, $70.2 \%$ work in private clinics, $18.3 \%$ in departmental institutions and $16.7 \%$ of respondents work in public health institutions. (Fig.2). At the same time, $52.0 \%$ of doctors in public hospitals, $42.1 \%$ of doctors in departmental institutions and $27.5 \%$ of doctors in private organizations said that they were relatively satisfied (more satisfied than not) with their salaries. In total, these two groups of answers ("completely satisfied" and "rather satisfied than not") demonstrate that $97.7 \%$ of doctors in private hospitals, $60.4 \%$ of doctors in departmental hospitals gave positive answers to the question, and $687 \%$ of doctors in public health facilities (Figure 2). The largest share of doctors who gave a negative feedback of their satisfaction with wages ("rather dissatisfied than satisfied" and "completely dissatisfied") was among employees in the departmental sector (39.6\%), while none of the respondents in the private sector noted their full dissatisfaction with salary. Doctors working in health care organizations of various affiliations also differ significantly in the level of greatest satisfaction with working conditions, which varies slightly among doctors in state and departmental institutions (37.8\% and $37.2 \%)$, but, at the same time, among doctors in private organizations, it is $85.3 \%$ (Fig.3). The cumulated measure of doctors' JS with working conditions in departmental institutions was $74.4 \%$, in state health care organizations was $86.6 \%$, and in private clinics - 100\%. At the same time, none of the respondents in private clinics expressed their dissatisfaction with working conditions. The total level of JS with the team atmosphere is very high among doctors in all types of medical organizations (67 - 69\%), and slightly differs from each other (Fig.4). Less than $6 \%$ of respondents from each type of medical organization said that they were not satisfied with the situation in their team. Almost three-quarters (74\%) of doctors working in public health care institutions said they would like to see improvements in the equipment of their clinics, compared with $56 \%$ of doctors in the departmental sector and $18 \%$ of doctors in the private sector. (Table1). In addition, about a third of respondents in the public and departmental sectors $(29 \%$ and $33 \%)$ said that there was a need to improve the ability to regularly use professional medical resources on the Internet at their workplace [Ahmadi et al, 2014]. Also, that 40\% of doctors in departmental institutions expressed their wishes to reduce the workload, while the share of doctors working in public and private clinics and expressed similar wishes amounted to only $27 \%$ and $15 \%$. When determining the importance of incentives for doctors, analysis of the results of the survey showed that salary increase is by far the leading position and the most important incentive for respondents in all types of 
institutions (93\% - 84\%) (Table 2). Also, more than half of doctors in state and departmental heath care institutions noted the improvement of working conditions as the second most important incentive (53\% and $56 \%$, respectively) [Bussing, 2002]. The recognition of the professional community is also very much appreciated by doctors in departmental and private organizations ( $43 \%$ and $40 \%$ respectively), in contrast to public sector doctors (21\%). Incentives such as career growth or empowerment showed a very low demand and less than $15 \%$ of respondents were noted. To determine the influence of one or another factor, among the respondents in state, departmental, or private institutions, a logistic regression analysis of the survey results was performed for each type of medical organization. The coefficients for the independent variables depending on the types of healthcare organizations are shown in Table 3. According to the results of logistic regression, model correlations for state medical organizations are statistically significant $(p<0.05, x 2(4)=$ 11.724). The explained variation of the dependent variable, based on our model, is $16.7 \%$ (Nagelkerke R2). The results also show that for government healthcare organizations only one variable is statistically significant: "satisfaction with working conditions" $(p<0.05)$. The correlation coefficients between such variables as "salary satisfaction" and "satisfaction with the team atmosphere" with the general level of job satisfaction are also statistically significant (Table 4). Thus, the variables "salary satisfaction" and "satisfaction with the team atmosphere" positively affect job satisfaction (JS). The set of model variables for departmental medical organizations shows a significant correlation $(p<0.0005, x 2(4)=40.172)$. The model accounts for $44.3 \%$ of the variation of the dependent variable. In this model, two variables are statistically significant: "satisfaction with wages" $(p<0.01)$ and "satisfaction with working conditions" $(p<0.005)$, of which the level of satisfaction of workers with their wages more significantly affects the overall level of satisfaction with work (Table 3). The "team atmosphere satisfaction" variable indicates a positive significant correlation with JS ( $p$ $<0.005)$.

The revealed effect of multicollinearity between the independent factors "satisfaction with working conditions" and "satisfaction with the atmosphere of the team" served as the basis for the exclusion of the variable "satisfaction with working conditions" from the model.

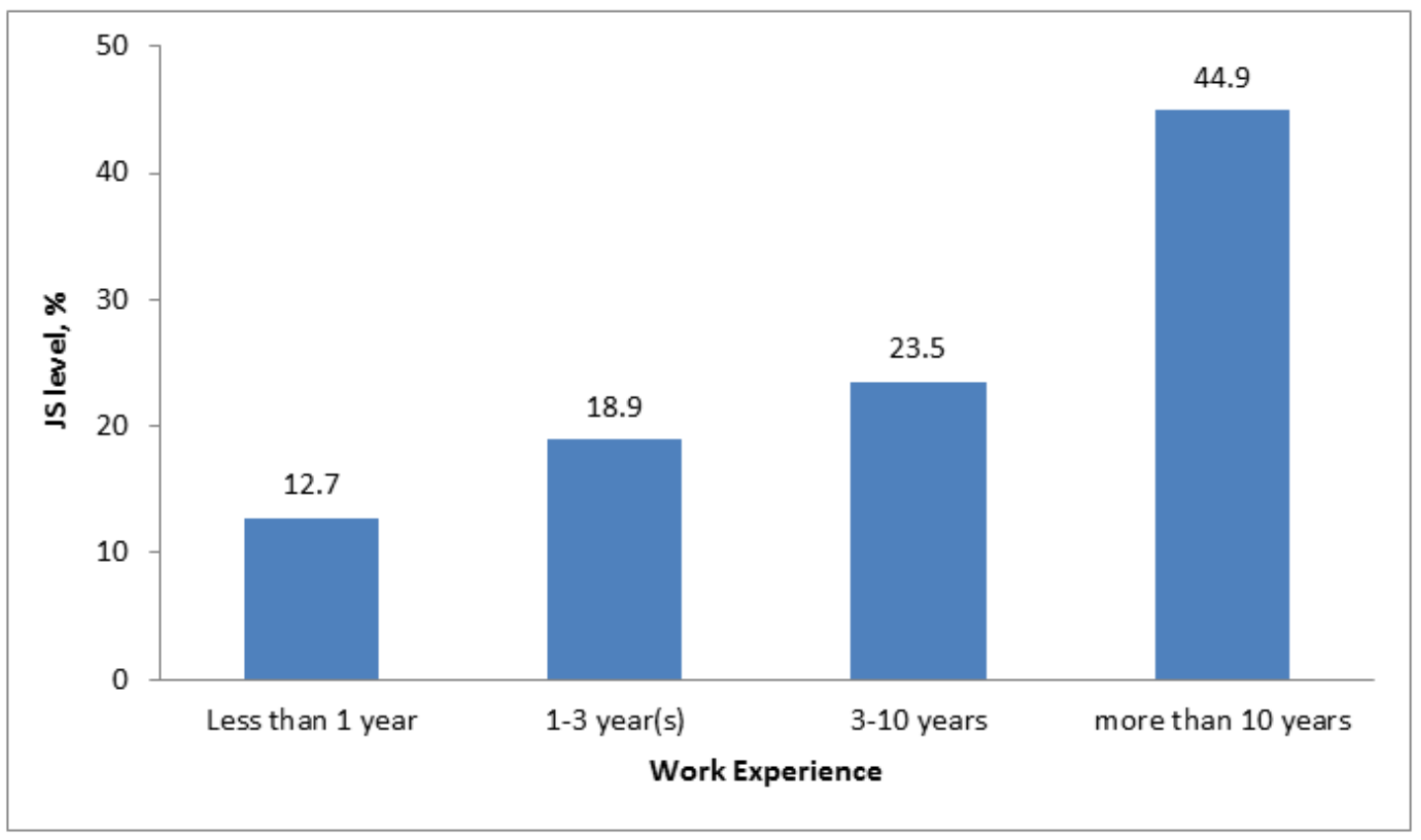

Figure 1. JS level of doctors depending on the length of service. 


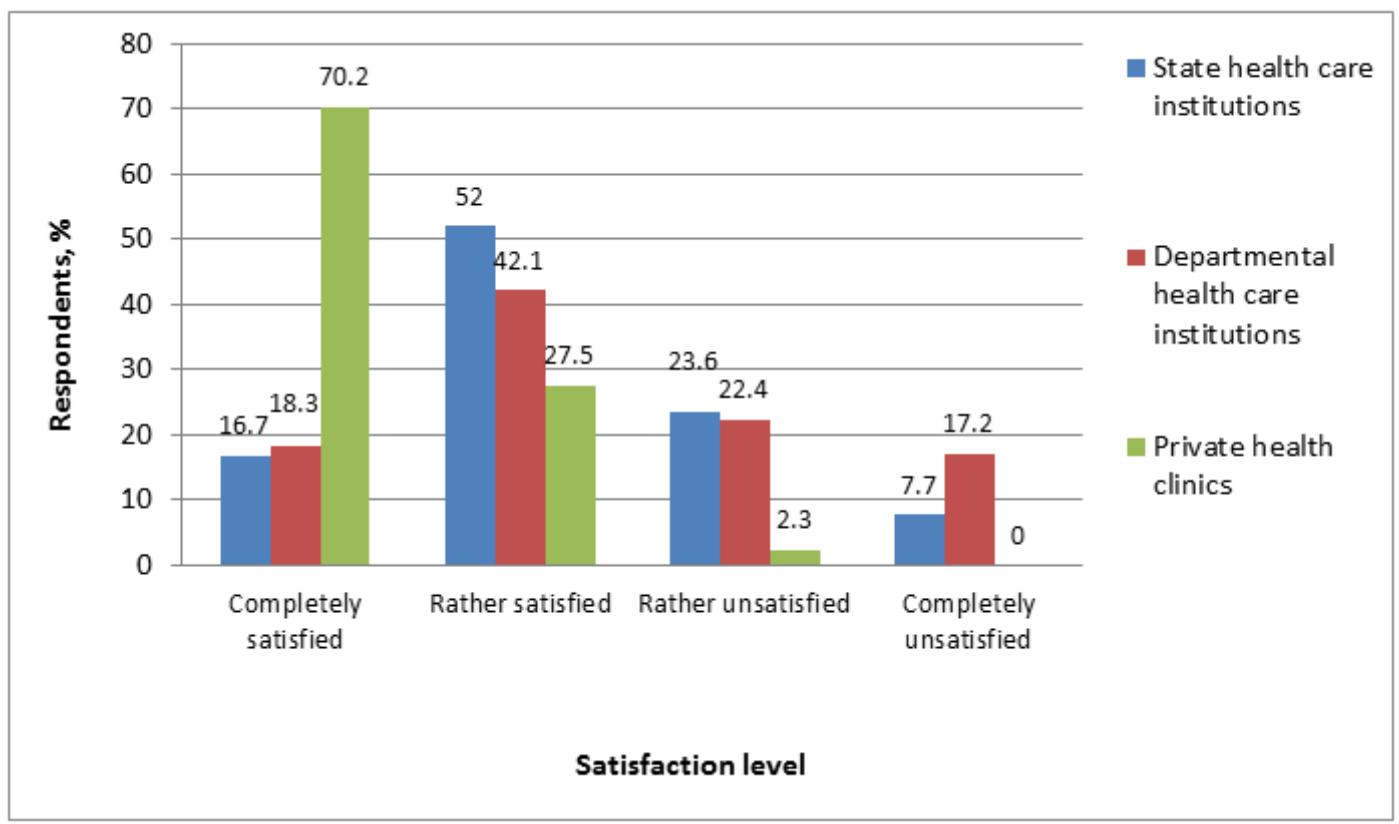

Figure 2. JS level of doctors with salaries in various types of health care organizations.

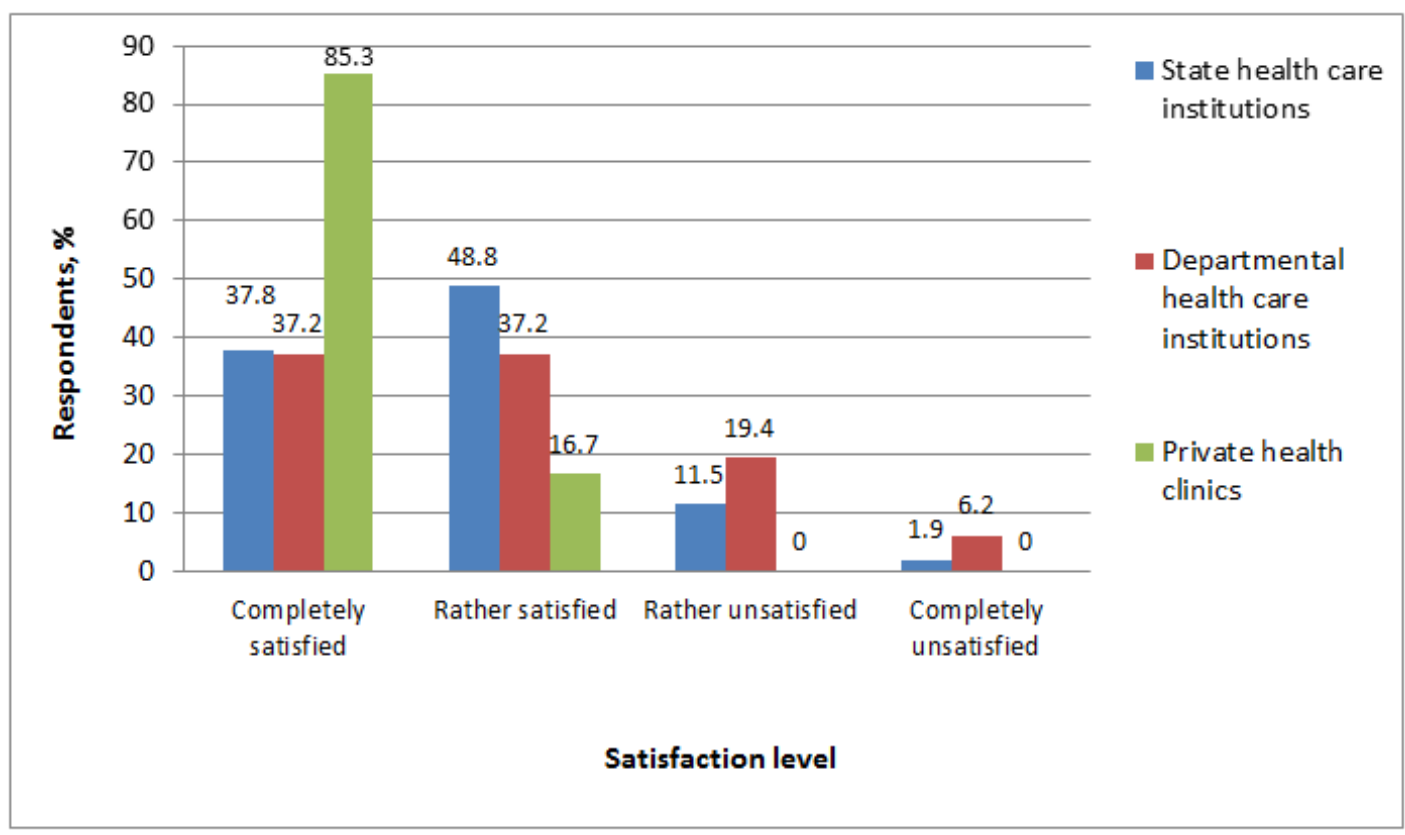

Figure 3. JS level of doctors with working conditions in various types of health care organizations. 


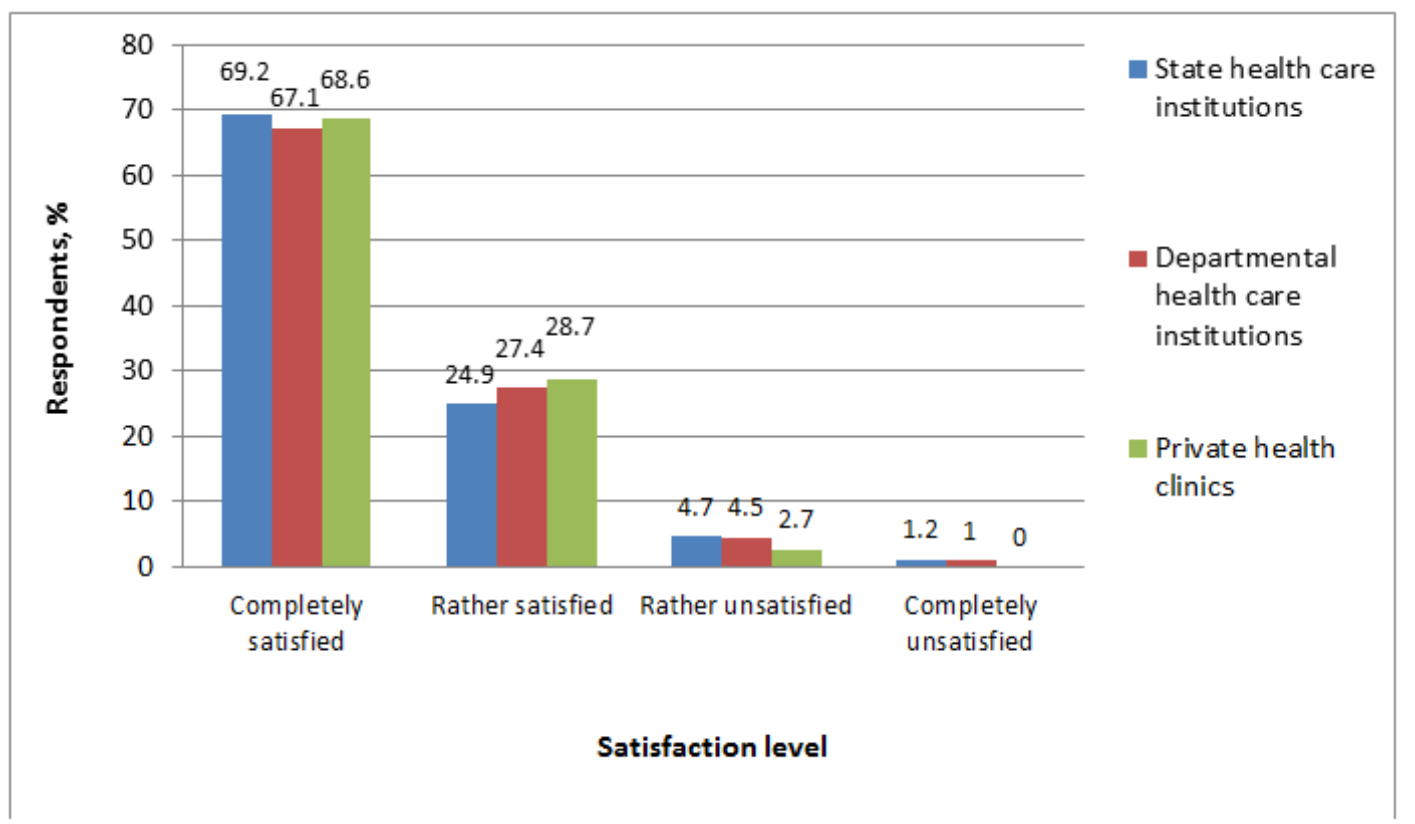

Figure 4. JS level of doctors with the atmosphere of the team in various types of health care organizations, $\%$

Table 1. Work conditions aspects that doctors would like to see improved.

\begin{tabular}{|c|c|c|c|}
\hline \multirow{2}{*}{$\begin{array}{l}\text { Work conditions aspects } \\
\text { that doctors would like to } \\
\text { see improved (\% of } \\
\text { respondents) }\end{array}$} & \multicolumn{3}{|c|}{ Types of health care institutions } \\
\hline & $\begin{array}{l}\text { State health care } \\
\text { institutions } \\
\text { (\% of respondents in } \\
\text { state health care } \\
\text { institutions) }\end{array}$ & $\begin{array}{l}\text { Departmental health } \\
\text { care institutions } \\
\text { (\% of respondents in } \\
\text { departmental health } \\
\text { care institutions) }\end{array}$ & $\begin{array}{l}\text { Private health clinics (\% } \\
\text { of respondents in private } \\
\text { health clinics) }\end{array}$ \\
\hline Best equipment & $74 \%$ & $56 \%$ & $18 \%$ \\
\hline $\begin{array}{l}\text { Access to professional } \\
\text { medical resources on } \\
\text { the Internet }\end{array}$ & $29 \%$ & $33 \%$ & $0 \%$ \\
\hline Workload reduction & $27 \%$ & $40 \%$ & $15 \%$ \\
\hline
\end{tabular}

Table 2. The importance of various incentives for doctors, according to respondents.

\begin{tabular}{|c|c|c|c|}
\hline \multirow{2}{*}{$\begin{array}{l}\text { Work conditions aspects } \\
\text { that doctors would like to } \\
\text { see improved ( } \% \text { of } \\
\text { respondents) }\end{array}$} & \multicolumn{3}{|c|}{ Types of health care institutions } \\
\hline & $\begin{array}{l}\text { State health care } \\
\text { institutions } \\
\text { (\% of respondents in } \\
\text { state health care } \\
\text { institutions) }\end{array}$ & $\begin{array}{l}\text { Departmental health } \\
\text { care institutions } \\
\text { (\% of respondents in } \\
\text { departmental health } \\
\text { care institutions) }\end{array}$ & $\begin{array}{l}\text { Private health clinics (\% } \\
\text { of respondents in private } \\
\text { health clinics) }\end{array}$ \\
\hline Promotion & $89 \%$ & $93 \%$ & $84 \%$ \\
\hline $\begin{array}{l}\text { Improving } \\
\text { conditions }\end{array}$ & $53 \%$ & $56 \%$ & $20 \%$ \\
\hline Community recognition & $21 \%$ & $43 \%$ & $40 \%$ \\
\hline Empowerment & $9 \%$ & $7 \%$ & $13 \%$ \\
\hline Career growth & $7 \%$ & $9 \%$ & $13 \%$ \\
\hline
\end{tabular}


Table 3. Logistic regression predicting the likelihood that doctors will report that they will be satisfied based on their salary, working conditions and team atmosphere.

\begin{tabular}{|l|l|l|l|l|l|l|}
\hline \multirow{7}{*}{} & \multicolumn{6}{l}{ Types of health care institutions } \\
\cline { 2 - 7 } & $\begin{array}{l}\text { State health care } \\
\text { institutions }\end{array}$ & \multicolumn{2}{l|}{$\begin{array}{l}\text { Departmental health } \\
\text { care institutions }\end{array}$} & \multicolumn{2}{l|}{ Private health clinics } \\
\cline { 2 - 7 } & Sig. & $\operatorname{Exp}(\mathrm{B})$ & Sig. & $\operatorname{Exp}(\mathrm{B})$ & Sig. & Exp(B) \\
\hline Constant & 0,327 & 5,337 & 0,282 & 0,219 & 0,038 & 0,032 \\
\hline Salary Satisfaction & 0,292 & 2,214 & 0,007 & 18,030 & 0,010 & 10,642 \\
\hline $\begin{array}{l}\text { Work conditions } \\
\text { satisfaction }\end{array}$ & 0,006 & 7,110 & 0,004 & 8,080 & - & - \\
\hline $\begin{array}{l}\text { Team atmosphere } \\
\text { satisfaction }\end{array}$ & 0,981 & 0,972 & 0,182 & 3,144 & 0,104 & 3,676 \\
\hline
\end{tabular}

Table 4. Correlation coefficients with the variable "job satisfaction".

\begin{tabular}{|l|l|l|l|l|}
\hline \multicolumn{2}{|c|}{} & \multicolumn{3}{|l|}{ Types of health care institutions } \\
\cline { 3 - 5 } & $\begin{array}{l}\text { Community health } \\
\text { care institutions }\end{array}$ & $\begin{array}{l}\text { Departmental health } \\
\text { care institutions }\end{array}$ & $\begin{array}{l}\text { Private health } \\
\text { clinics }\end{array}$ \\
\hline $\begin{array}{l}\text { Pearson } \\
\text { Correlation }\end{array}$ & Salary Satisfaction & 0,186 & 0,347 & 0,587 \\
\cline { 2 - 5 } & $\begin{array}{l}\text { Work conditions } \\
\text { satisfaction }\end{array}$ & 0,310 & 0,375 & 0,607 \\
\cline { 2 - 5 } & $\begin{array}{l}\text { Team atmosphere } \\
\text { satisfaction }\end{array}$ & 0,106 & 0,347 & 0,456 \\
\hline $\begin{array}{l}\text { Significance } \\
\text { (1-tailed) }\end{array}$ & Salary Satisfaction & 0,002 & 0,000 & 0,000 \\
\cline { 2 - 5 } & $\begin{array}{l}\text { Work conditions } \\
\text { satisfaction }\end{array}$ & 0,000 & 0,000 & 0,000 \\
\cline { 2 - 5 } & $\begin{array}{l}\text { Team atmosphere } \\
\text { satisfaction }\end{array}$ & 0,043 & 0,000 & 0,001 \\
\hline
\end{tabular}

\section{DISCUSSION}

The findings of the study indicated that in 2019 doctors working in departmental health care institutions are less satisfied with their work than doctors in state organizations and, especially, private clinics $(54.1 \%, 59.7 \%$, and 67.1\%). Moreover, in comparison with the results of a similar study conducted by M. Shkolnikova, M. Yugay, and V. Pankevich in 2017, the level of satisfaction with their work among public sector doctors increased by $3.4 \%$, and the level of JS doctors of departmental organizations decreased by $4.1 \%$, while satisfaction with the work among doctors in the private sector remains maximum, despite a slight decrease $(0.2 \%)$. Also, during the research, it was found that doctors working in departmental health care organizations are less satisfied with their salaries than doctors in state health care institutions and private clinics $(64.7 \%$, $68.4 \%$ and $97.7 \%$, respectively) Moreover, in comparison with the results of a similar study in 2017 , the total level of satisfaction with their wages among public sector doctors increased by $12.1 \%$, and the level of JS doctors of departmental organizations decreased by $4.2 \%$, while the satisfaction with work among private physicians has remained almost at the same level [Shkolnikova et al, 2017]. Retrospective analysis of the research results confirms the effectiveness of the current reforms of the healthcare system in Moscow, which include a transition to an effective contract, an increase in wages and equipping public institutions with information systems and modern equipment, the level of competitiveness of public hospitals is growing and many private medical institutions cannot compete and stop its activities. In spite of the observance of the 
condition of anonymity of the respondents, it is likely that doctors in private clinics did not report their dissatisfaction with their work because of fear of publicizing the results of the survey and subsequent repressions, however, given the longitudinal but transverse nature of the study, this theory was not confirmed. For comparison, a survey in Jordan showed that JS levels are higher among doctors working in private health care institutions than among doctors working in public clinics [Bodur, 2002]. Our research showed that, in comparison with 2017, there is a tendency for maximum satisfaction with work among doctors with high experience in a particular health care organization, however, the satisfaction level of doctors with a working experience of less than 1 year increased by $6.4 \%$ and increased by $2.4 \%$ JS level of doctors with a working experience of 1 to 3 years [Shkolnikova et al, 2017]. We can assume that although experienced workers with more experience are more adapted to the conditions of work in a particular organization, at the same time, the interest of many leaders of the organization in updating the team, the introduction of the "institute of mentors" and interest in the professional growth of young employees allows accelerate their adaptation to the clinic team. It is also established that the degree of doctors' satisfaction of the team's atmosphere (the situation at the workplace) is quite high and does not depend on the type of healthcare organization. A small proportion $(0 \%-1 \%)$ of respondents who indicated their dissatisfaction with this aspect, which confirms the statement about the importance of a healthy team atmosphere for medical practice, where corporate values, cooperation and mutual assistance are key elements. Similar studies of doctors' job satisfaction conducted in Moscow in 2010 and 2017 showed that more than 80\% of doctors are satisfied with relationships with their colleagues [2, 22]. Frequent mention by respondents of the desire to improve equipment in state medical organizations (Table 2) is a confirmation of the correctness of the chosen policy of the Government of Moscow aimed at improving material support, equipping with modern medical equipment and the introduction of electronic medical systems in state healthcare institutions. The leading position in the incentive rating is occupied by "salary increase", which was noted by about $90 \%$ of the doctors surveyed, provided that only $10 \%$ of the respondents said that they value career growth most highly (Table 3 ). These data confirm the results of the study in 2017 and confirm the high practical value of the "performance-based contract of employment" as a motivating factor that significantly affects the overall satisfaction of doctors with their work. An analysis of logistic regression showed that in government organizations, working conditions are the factor that has the greatest impact on the overall level of satisfaction with the work of doctors. In this study, the term "working conditions" meant not only the physical conditions at the workplace, but also the organization of the work process. The fact that in Russia the length of the workday (working hours) for doctors in state healthcare organizations is clearly regulated and often inferior to the actual working hours for doctors in private and departmental clinics, may explain these results. In private healthcare facilities, salaries have the greatest impact on the level of doctors' JS. Doctors in this sector, as a rule, receive a salary slightly higher than in other sectors, mainly because private clinics are more active in a competitive environment and, therefore, should provide better conditions for both patients and workers, however progressive tendencies for increasing the salaries of public sector health workers and strengthening the competitiveness of state medical institutions are capable of changing the balance in the area of job satisfaction in the near future that. In each regression logistic analysis and for each type of healthcare organization, a factor was identified that is especially important for respondent satisfaction. It should be noted that all the factors that have been studied are important in the employee motivation system, which is confirmed by statistically significant correlation coefficients for each type of organization (Table 4). This fact should be taken into account when developing tools for developing a system of motivation and increasing the level of satisfaction with the work of health care employees. 


\section{CONCLUSION}

A survey of 1876 doctors working in various types of health care organizations in Moscow showed that doctors in private clinics have the highest average level of job satisfaction (67.1\%), while the number of JS specialists has increased, with minimal work experience. In 2019, the cumulative doctor's satisfaction rate with salaries in state institutions exceeded the level of departmental organizations. However, it is still significantly inferior to the private health sector. Also, in the period from 2017 to 2019, the level of satisfaction of doctors of state clinics with working conditions increased. It was also revealed that the level of satisfaction with the atmosphere of the team is quite high (about $70 \%$ ) among doctors of all types of medical organizations and has not changed since 2017.

Analysis indicated that statistically main factors that influence the likelihood that a doctor will be satisfied with his work are: in state medical institutions and in departmental organizations - satisfaction with wages and working conditions, in private clinics - satisfaction with wages.

These results indicate that the levels of satisfaction with the work of doctors, which, in turn, affect the efficiency of their work, can be increased by increasing compensation and improving working conditions. This can be done by improving the motivation system in institutions, as through the use of material incentives as part of an "effective contract" with employees and by providing various non-financial incentives.

\section{REFERENCES}

Adams J.S. (1965). Inequity in Social Exchange. Advances in Experimental Social Psychology, 2, 267 299. https://doi.org/10.1016/s0065-2601(08)60108-2

Ahmadi, A.K , Mohammad Pour, B , Zamani, B.(2014). Study of relationship between Organizational Culture and Employees Readiness: a Case study of Isfahan University, UCT Journal of Social Sciences and Humanities Research, Issue 2,pp.29-35.

Bodrov V.A. (2007). Job satisfaction as a subjective indicator of professional suitability. The human factor: problems of psychology and ergonomics, 3, 2-9.

Bodur S. (2002). Job Satisfaction of Health Care Staff Employed at Health Centers. Turkey Occupational Medicine, 6, 353-355. https://doi.org/10.1093/occmed/52.6.353

Bogue R.J., et al. (2006). Secrets of Physician Satisfaction. Physician Executive, 32, 30-39.

Bussing A. (2002). Motivation and satisfaction. Human Resource Management.

Cooper C.L., Rout U. and Faragher B. (1989). Mental Health, Job Satisfaction, and Job Stress among General Practitioners. BMJ, 298, 336. https://doi.org/10.1136/bmj.298.6670.366

Dewhurst M., Guthridge M. and Mohr E. (2009). Motivating People: Getting beyond Money. http://www.mckinsey.com/business-functions/organization/our-insights/motivating-people-gettingbeyond-money

Hackman J.R., Oldham G.R. (1976). Motivation through the Design of Work: Test of a Theory. Organizational Behavior and Human Performance, 2, 250-279. https://doi.org/10.1016/00305073(76)90016-7

Herzberg F., Mausner B. and Snyderman B.B. (2011). Motivation to Work. Transaction Publishers, Piscataway, 157.

House R.J., Wigdor L.A. (1967). Herzberg's Dualfactor Theory of Job Satisfaction and Motivation: A Review of the Evidence and a Criticism. Personnel Psychology, 4, 369-390. https://doi.org/10.1111/j.1744-6570.1967.tb02440.x 
Jex S.M., Britt T.W. (2014). Organizational Psychology: A Scientist-Practitioner Approach. John Wiley and Sons, New York, 706.

Judge T.A., Locke E.A. and Durham C.C. (1997). The Dispositional Causes of Job Satisfaction: A Core Evaluations Approach. Research in Organizational Behavior, 19, 151-188.

Kadyrov F.N. (2013). A new form of employment contract in the framework of the implementation of an effective contract / F.N. Kadyrov // Health Care Manager, № 4, 2013, p. 54 - 59.

Kuznecova A.M. (2013). Influence of priority factors of labor motivation on the choice of professional activities of medical workers.

Locke E.A. (1976). Nature and Causes of Job Satisfaction. Handbook of Industrial and Organizational Psychlogy, 1, 1297-1343.

Lysenko I.L., Chirkov V.A., Breusov A.V. and Mazitov M.R. (2014). Qualitative characteristics of medical personnel as the main component of the effectiveness of primary health care. Prakticheskaya Medicina (Health care in practice), 4, 65-68.

Medvedeva L. (2008). Labor satisfaction as a factor in increasing production efficiency. Economic Systems Management: Electronic Scientific Journal, 13, 37-45.

Nikic D., et al. (2008). Job Satisfaction in Health Care Workers. Acta Medica Medianae, 4, 9-12.

Peters, D.H., et al. (2010). Job Satisfaction and Motivation of Health Workers in Public and Private Sectors: Cross-Sectional Analysis from Two Indian States. Human Resources for Health, 8, 27. https://doi.org/10.1186/1478-4491-8-27

Rose M. (1994). Job Satisfaction, Job Skills, and Personal Skills. Penn Retal. Skill and Occupational Change, Oxford, 244-280.

Shkolnikova M., Yugay M. i Pankevich V. (2017). A comparative study of levels of satisfaction with the work of doctors in the public and private sectors in Russia. Scientific journal, 5, 101-113. (In Russ.) https://doi.org/10.4236/iss.2017.58008

Silaparasetti, V., Srinivasarao, G., \& Khan, F. R. (2017). structural equation modeling analysis using smart pls to assess the occupational health and safety (ohs) factors on workers' behavior. Humanities \& Social Sciences Reviews, 5(2), 88-97. https://doi.org/10.18510/hssr.2017.524

Smith P.C., Kendall L.M. and Hulin C.L. (1969). Measurement of Satisfaction in Work and Retirement. Rand Mc Nally, Chicago, IL, 194.

Spector P.E. (1997). Job Satisfaction: Application, Assessment, Causes, and Consequences. SAGE Publications, Thousand Oaks.

Yuriev V., Tarhanov, V. (2014). Self-esteem of doctors of various specialties of their social status and professional activities. Modern Problem Science and Education, 2, 310. http://www.scienceeducation.ru/ru/article/view?id=12498

This work is licensed under a Attribution-NonCommercial-NoDerivatives 4.0 International (CC BY-NC-ND 4.0). 